\title{
EFFECT OF LITHIUM CHLORIDE (Licl) DOPANT ON THE PERFORMANCE OF CATALYSTS FOR THE OXIDATIVE COUPLING OF METHANE
}

\author{
M. F. Mamat, N. A. Mohd Zabidi, S. Bhatia and M. H. A. Megat Ahmad \\ School of Chemical Engineering, Perak Branch Campus, Universiti Sains Malaysia,31750 Tronoh, Perak, \\ MALAYSIA \\ kkbhatia@kimia.eng.usm.my
}

\begin{abstract}
The present study reports effects of lithium chloride ( $\mathrm{LiCl}$ ) doping on $\mathrm{MgO}, \mathrm{La}_{2} \mathrm{O}_{3}, \mathrm{SnO}_{2}, \mathrm{CaO}$ and $\mathrm{ZnO}$ catalysts. All the catalysts were prepared by the impregnation method. The catalysts were tested at reaction temperature of $775^{\circ} \mathrm{C}$. The feed flow rate of methane, oxygen and nitrogen was carried out in the ratio of 3:1:2 giving a weight hourly space velocity (WHSV) of 0.375 g.s $/ \mathrm{cm}^{3} . \mathrm{La}_{2} \mathrm{O}_{3}$ showed the highest $\mathrm{C}_{2+}$ selectivity among the undoped catalysts. All the catalysts were doped with $\mathrm{LiCl}$ to compare their methane conversion, selectivity and product yield. The $2.0 \mathrm{~mol} \% \mathrm{LiCl}$ doped into $\mathrm{La}_{2} \mathrm{O}_{3}$ was the best catalyst formulation having achieved $46.7 \%$ of $\mathrm{C}_{2+}$ selectivity with $\mathrm{CH}_{4}$ conversion of $29.0 \%$ and the increase in selectivity was attributed to the presence of chlorine. Hydrogen production was more pronounced for $\mathrm{MgO}$ based catalysts and believed to be generated by surfacecatalyzed reactions.
\end{abstract}

Key Words: Oxidative Coupling, $\mathrm{C}_{2+}$ Selectivity, Hydrogen Production, Ethylene, Chlorine

\section{INTRODUCTION}

Direct conversion of methane to industrial organic compounds is particularly significant especially natural gas, where the major component is methane, is one of the most plentiful fossil fuels available. Industry analysts estimate that the world holds enough readily recoverable natural gas to produce 500 billion barrels of synthetic crude ${ }^{[1]}$. Perhaps triple that amount of gas can be found in coal seams, natural gas hydrates ${ }^{[2]}$ and in formations that release the gas only slowly. Crude oil is now the main source of chemicals and liquid fuels. However, with the continual depletion of crude oil reserve, the demand for natural gas as a source of chemicals and fuels would certainly increase ${ }^{[3]}$. One route is the direct dimerization of methane through the catalytic oxidative coupling of methane (OCM) process. The catalytic oxidative coupling of methane (OCM) is represented by the following equation:

$\mathrm{nCH}_{4}+\frac{\mathrm{y}}{2} \mathrm{O}_{2}{ }^{\circledR} \mathrm{C}_{\mathrm{n}} \mathrm{H}_{4 \mathrm{n}-2 \mathrm{y}}+\mathrm{yH}_{2} \mathrm{O}$

In most published works in this topic, $\mathrm{n}$ would have the optimum value of 2. Oxidant other than $\mathrm{O}_{2}$, such as $\mathrm{N}_{2} \mathrm{O}$ and $\mathrm{O}_{3}$ have also been shown to facilitate the coupling reaction ${ }^{[4]}$.

The hydrocarbon products are often reported as $\mathrm{C}_{2+}$ products, mostly ethane and ethylene as the major components with ethylene as the target product. $\mathrm{C}_{3}$ hydrocarbons are usually formed but at comparatively low selectivity. In addition to these products, $\mathrm{CO}_{\mathrm{x}}(\mathrm{CO}$ and $\left.\mathrm{CO}_{2}\right)$ are also formed nonselectively. The conversion of $\mathrm{CH}_{4}$ to $\mathrm{CO}_{\mathrm{x}}$ is undesirable since it represents a lower yield of hydrocarbons. The $\mathrm{CO}_{\mathrm{x}}$ may also poison the surface of the catalyst. Another important product from the reaction is hydrogen, which is also a valuable product especially in fuel cells, which is projected to become the main source of energy for automobiles ${ }^{[5]}$.

A large number of compounds, mostly metal oxides has been tested and found capable of facilitating the oxidative coupling reaction. In most of the catalysts studied, reaction temperatures in the range of $700-900^{\circ} \mathrm{C}$ are needed and products consists of $\mathrm{C}_{2+}$ hydrocarbons, carbon monoxide, carbon dioxide and water are obtained. There appears to be an inverse relation between methane conversion and selectivity to $\mathrm{C}_{2}$ hydrocarbons, resulting in an upper limit of selectivity per pass through the reactor. Indeed, investigation on the thermodynamic feasibility of the reactions, proposed that ethylene yield of 30 per cent is the highest that can be achieved ${ }^{[6]}$.

In earlier studies, the goal of the applied research was often to maximize $\mathrm{C}_{2+}$ yield by varying composition of the catalyst, partial pressures of reactants, etc.; however, even in the best catalytic systems, the $\mathrm{C}_{2+}$ hydrocarbons concentration in the exit gas were quite low making it economically undesirable to extract $\mathrm{C}_{2+}$ from such a mixture.

The more effective catalysts may be divided into five groups a) highly basic pure oxides, of which the early members of the lanthanide oxides series (excluding $\mathrm{CeO}_{2}$ ) are the best, b) Group IA or IIA ions supported on basic oxides (for example, $\mathrm{Li} / \mathrm{MgO}, \mathrm{Ba} / \mathrm{MgO}$ and $\mathrm{Sr} / \mathrm{La}_{2} \mathrm{O}_{3}$ ), c) monophasic oxides, d) a few transition metal oxides that contain Group IA ions, and e) any of these materials that are promoted with chloride ions.

It is very unlikely that only a single type of site is responsible for the activation of methane as can be seen in the diversity of the catalysts used in the oxidative coupling reaction. It is difficult to determine the nature of the active sites as most characterization methods are 
applicable only at conditions far removed from those used in the actual catalytic reaction. Nonetheless, rational hypothesis can be made concerning the species that might exist on the surface of the functioning catalysts.

The addition of chloride ions to an oxidative coupling catalyst can have a marked effect on its properties, particularly with respect to the ethylene $\left(\mathrm{C}_{2} \mathrm{H}_{4}\right)$ to ethane $\left(\mathrm{C}_{2} \mathrm{H}_{6}\right)$ product ratio. The chloride may be introduced either initially as a part of the catalyst or through organo chlorine compounds, for instance $\mathrm{CCl}_{4}$, that are added to the reagents ${ }^{[7]}$. Because chlorine is known to dehydrogenate $\mathrm{C}_{2} \mathrm{H}_{6}$ in the gas phase, it has been suspected that homogenous reactions may be responsible for the large $\mathrm{C}_{2} \mathrm{H}_{4} / \mathrm{C}_{2} \mathrm{H}_{6}$ ratios that are observed in these chlorine containing systems ${ }^{[8]}$. In this study, the effects of $\mathrm{LiCl}$ on different oxide catalysts such as $\mathrm{MgO}, \mathrm{La}_{2} \mathrm{O}_{3}, \mathrm{SnO}_{2}, \mathrm{CaO}$ and $\mathrm{ZnO}$ are reported.

\section{EXPERIMENTAL}

Catalysts were prepared through the wet impregnation method. Powdered MgO (Merck, extra high purity), $\mathrm{La}_{2} \mathrm{O}_{3}$ (Fluka, purity 97\%), $\mathrm{CaO}(\mathrm{BDH}), \mathrm{ZnO}$ (Merck, 99.0\%) and $\mathrm{SnO}_{2}$ (Merck, 99.0\%) were used directly from supplier's package without any treatment. For doping the catalysts with $\mathrm{LiCl}$, desired amount of $\mathrm{LiCl}$ (Merck, 98.0\%) was dissolved in deionized water. The supports were then poured into the solution and stirred. The resulting paste was dried in an oven for $12 \mathrm{hrs}$ at $110^{\circ} \mathrm{C}-120^{\circ} \mathrm{C}$. The dried paste was then crushed to powder and calcined at $950^{\circ} \mathrm{C}$ for 4 hour. The calcined material was then pelletized at 5 tons $/ \mathrm{m}^{2}$ for each $5 \mathrm{gm}$ of catalyst. The pellet was then calcined again at $950^{\circ} \mathrm{C}$ for another $8 \mathrm{hrs}$. After calcination, the pellets were crushed and sieved to 40-60 mesh size. The same procedure was applied with the other dopant $\left(\mathrm{Li}_{2} \mathrm{CO}_{3}\right.$, Ajax, 99.5\%) used before testing.

The catalysts were tested in a stainless steel microreactor (O.D. $12.7 \mathrm{~mm}$, I.D. $10.92 \mathrm{~mm}$ and length $600 \mathrm{~mm}$ ) situated vertically in a tubular furnace (Carbolite VST 12). The catalyst layer was placed in the center of the microreactor. The free space below and above the catalyst layer was filled with quartz particles (RDH) of 40-60 mesh size in order to minimize the dead volume of the reactor. Methane (Malaysian Oxygen, purity 99.99\%), Oxygen (99.8\%) and Nitrogen $(99.99 \%)$ were passed through the microreactor. Flow of the gases was controlled using mass flow controllers (Brooks 5850E for both nitrogen and oxygen and MKS for methane). Outlet gas flow rate was monitored using a gas flowmeter (Alexander Wright DM3 B). The gaseous products were analyzed using an on-line gas chromatograph (Hewlett-Packard 6890). Porapaq N column was used to separate carbon dioxide, ethane, ethylene and propylene and Molecular Sieve 5A was used for separation of hydrogen, oxygen, carbon monoxide, nitrogen and methane. Water, a by-product of the reaction, was trapped in a gas trap before gaseous product sampling was carried out. The gas chromatograph was calibrated using a standard gas mixture supplied by BOC Gases, U.K.
The catalyst was first heated in $\mathrm{O}_{2}$ at a flow rate of 10 $\mathrm{ml} / \mathrm{min}$ at $800^{\circ} \mathrm{C}$ for half an hour to oxidize adsorbed components. It was then cooled down to $700^{\circ} \mathrm{C}$ before mixture of reactants was fed through the microreactor with $\mathrm{CH}_{4}: \mathrm{O}_{2}: \mathrm{N}_{2}$ ratio of 3:1:2 giving a total flow rate of $240 \mathrm{ml} / \mathrm{min}$. A $1.5 \mathrm{gm}$ of catalyst was used for each experimental run. Furnace temperature was adjusted to the desired reaction temperature. Catalyst bed temperature was monitored using a Chromel-Alumel thermocouple inserted into the catalyst bed. Once the bed temperature stabilized for 15 mins, the sample was drawn.

The activity of the catalysts was expressed in terms of methane conversion, selectivity and yield for $\mathrm{C}_{2+}$ hydrocarbon and hydrogen. A carbon balance of $100 \pm 2 \%$ was obtained for every run over the catalysts. The conversion of methane or oxygen was defined as

$$
\begin{aligned}
& \mathrm{X}\left(\mathrm{CH}_{4} \text { or } \mathrm{O}_{2}\right)= \\
& \frac{\text { moles } \mathrm{CH}_{4} \text { or } \mathrm{O}_{2} \text { converted }}{\text { moles } \mathrm{CH}_{4} \text { or } \mathrm{O}_{2} \text { fed }}, 100 \%
\end{aligned}
$$

The selectivity for $\mathrm{C}_{\mathrm{n}}$ products was calculated as

$$
\begin{aligned}
& \mathrm{S}\left(\mathrm{C}_{\mathrm{n}}\right)= \\
& \frac{\mathrm{n}^{\prime} \text { moles } \mathrm{C}_{\mathrm{n}} \text { in products }}{\text { moles } \mathrm{CH}_{4} \text { converted to all products }}, 100 \%
\end{aligned}
$$

The yield for $C_{n}$ product was given by

$$
\mathrm{Y}\left(\mathrm{C}_{\mathrm{n}}\right)=\frac{\mathrm{n}^{\prime} \text { moles } \mathrm{C}_{\mathrm{n}} \text { in products }}{\text { moles } \mathrm{CH}_{4} \text { fed }}, 100 \%
$$

The selectivity for $\mathrm{H}_{2}$ product was calculated as

$$
\begin{aligned}
& \mathrm{S}\left(\mathrm{H}_{2}\right)= \\
& \frac{2^{\prime} \text { moles } \mathrm{H}_{2} \text { in products }}{4^{\prime} \text { moles } \mathrm{CH}_{4} \text { converted to all products }} \\
& \text { The yield for } \mathrm{H}_{2} \text { product was given by } \\
& \mathrm{Y}\left(\mathrm{C}_{\mathrm{n}}\right)=\frac{2^{\prime}{\text { moles } \mathrm{H}_{2} \text { in products }}_{\text {moles } \mathrm{CH}_{4} \text { fed }}}{\text { med }^{\prime}} 100 \%
\end{aligned}
$$

\section{RESULTS}

In most of experimental runs, methane to oxygen mole ratio was more than 2 . A $100 \% \quad \mathrm{O}_{2}$ conversion was achieved in most of experiments. Figure 1 shows the methane conversion, selectivity and yield of $\mathrm{C}_{2+}$ hydrocarbons for undoped catalysts. $\mathrm{La}_{2} \mathrm{O}_{3}$ gives the highest activity in terms of selectivity and yield of $\mathrm{C}_{2+}$ hydrocarbons, which were $44.8 \%$ and $12.4 \%$ respectively, followed by $\mathrm{MgO}$ with $39.4 \%$ selectivity and yield of $11.3 \%$ of $\mathrm{C}_{2+}$ hydrocarbons.

$\mathrm{ZnO}$ gave $18.8 \%$ selectivity $\mathrm{OF} \mathrm{C}_{2+}$ hydrocarbons and yield of $4.0 \%$. Catalytic performance of both $\mathrm{SnO}_{2}$ and $\mathrm{CaO}$ show that they are nonselective catalysts. All these results are in line with literature findings. Both the $\mathrm{La}_{2} \mathrm{O}_{3}$ and $\mathrm{MgO}$ have been known to be good coupling catalysts especially when doped with alkaline earth oxides $^{[9]}$. 
Fig. 1 Performance of undoped catalyst

Figure 2 shows the selectivity and yield of hydrogen for the undoped catalysts. $\mathrm{MgO}$ showed the highest activity with $\mathrm{H}_{2}$ selectivity of $19.1 \%$ and yield of $5.5 \%$. Compared to the selectivity and yield of hydrocarbons product, $\mathrm{CaO}$ showed significant selectivity and yield of $\mathrm{H}_{2}$ relative to $\mathrm{MgO}$. A selectivity of $12.0 \%$ and $2.7 \%$ yield of hydrogen were obtained. Both $\mathrm{SnO}_{2}$ and $\mathrm{ZnO}$ gave low activity to $\mathrm{H}_{2}$ formation.

The ratios of $\mathrm{C}_{2} \mathrm{H}_{4} / \mathrm{C}_{2} \mathrm{H}_{6}$ and $\mathrm{CO} / \mathrm{CO}_{2}$ are shown in Figure 3. From these results, it appeared that higher $\mathrm{C}_{2+}$ selectivity leads to higher $\mathrm{C}_{2} \mathrm{H}_{4} / \mathrm{C}_{2} \mathrm{H}_{6}$ ratio, nevertheless a small degree of variation in catalytic activity among the catalysts was observed. $\mathrm{MgO}$ produced higher ethylene relative to ethane as compared to $\mathrm{La}_{2} \mathrm{O}_{3}$ even though $\mathrm{La}_{2} \mathrm{O}_{3}$ gave the highest selectivity to $\mathrm{C}_{2+}$ hydrocarbons. The $\mathrm{C}_{2} \mathrm{H}_{4} / \mathrm{C}_{2} \mathrm{H}_{6}$ ratio did not correlate with $\mathrm{H}_{2}$ selectivity and yield.

Fig. 2 Activity of undoped catalyst for selectivity and yield of hydrogen production
Fig. 3 Ethylene to ethane ratio and carbon monoxide to carbon dioxide ratio over undoped catalyst

Doping the catalysts with $1 \mathrm{~mol} \% \mathrm{LiCl}$ did not result in an apparent increase in terms of $\mathrm{C}_{2+}$ selectivity and yield for any of the catalysts except $\mathrm{CaO}$, as shown in Figure 4. The $\mathrm{C}_{2+}$ selectivity of $1 \mathrm{~mol} \% \mathrm{LiCl} / \mathrm{CaO}$ increased much higher compared to the other catalysts but the methane conversion decreased. The $\mathrm{C}_{2+}$ selectivity increased from $7.6 \%$ to $17.2 \%$ wihile methane conversion dropped $22.8 \%$ to $18.8 \%$. No marked changes in the measured parameters were observed for other $1 \mathrm{~mol} \% \mathrm{LiCl}$ doped catalysts.

Figure 5 shows the selectivity and yield of $\mathrm{H}_{2}$ on the $1 \mathrm{~mol} \% \mathrm{LiCl}$ doped catalysts. Again, except for $1 \mathrm{~mol} \%$ $\mathrm{LiCl} / \mathrm{CaO}$, there are no significant changes in both the $\mathrm{H}_{2}$ selectivity and yield for the other catalysts. The $\mathrm{H}_{2}$ selectivity and yield for $1 \mathrm{~mol} \% \mathrm{LiCl} / \mathrm{CaO}$ catalysts decreased from $12.0 \%$ to $0.9 \%$ and from $2.7 \%$ to $0.2 \%$, respectively.
Fig. 4 Activity of $1 \mathrm{~mol} \%$ of $\mathrm{LiCl}$ doped catalysts 
Fig. 5 Hydrogen production over $1 \mathrm{~mol} \% \mathrm{LiCl}$ doped catalyst

Figure 6 shows the ratios of $\mathrm{C}_{2} \mathrm{H}_{4} / \mathrm{C}_{2} \mathrm{H}_{6}$ and $\mathrm{CO} / \mathrm{CO}_{2}$ against the $1 \mathrm{~mol} \% \mathrm{LiCl}$ doped catalysts. The presence of $\mathrm{LiCl}$ appears to have a conspicuous influence to the product ratios, especially doped $\mathrm{MgO}$ catalyst. The ratio of $\mathrm{C}_{2} \mathrm{H}_{4} / \mathrm{C}_{2} \mathrm{H}_{6}$ increased from 1.14 for $\mathrm{MgO}$ catalyst to 1.38 for $1 \mathrm{~mol} \% \mathrm{LiCl} / \mathrm{MgO}$ whereas the $\mathrm{CO} / \mathrm{CO}_{2}$ increased from 0.14 to 0.25 . For the other catalysts, no significant changes were observed in $\mathrm{C}_{2} \mathrm{H}_{4} / \mathrm{C}_{2} \mathrm{H}_{6}$ ratio but the $\mathrm{CO} / \mathrm{CO}_{2}$ ratio for $\mathrm{CaO}$ and $\mathrm{SnO}_{2}$ reduced markedly due to total oxidation to $\mathrm{CO}_{2}$.

Because of its high selectitivity to $\mathrm{C}_{2+}$ hydrocarbons, both the $\mathrm{La}_{2} \mathrm{O}_{3}$ and $\mathrm{MgO}$ have been doped with $2 \mathrm{~mol} \%$ $\mathrm{LiCl}$. Table 1 shows the results of these catalysts together with pure and $1 \mathrm{~mol} \% \mathrm{LiCl}$ doped catalysts for comparison purpose.
Fig. 6 Products ratio over $1 \mathrm{~mol} \% \mathrm{LiCl}$ doped catalyst

From Table 1, increasing $\mathrm{LiCl}$ concentration on $\mathrm{MgO}$ resulted in a negative effect where the $\mathrm{C}_{2+}$ selectivity decreased from $39.6 \%$ for $1 \mathrm{~mol} \% \mathrm{LiCl} / \mathrm{MgO}$ catalyst to $34.7 \%$ for $2 \mathrm{~mol} \% \mathrm{LiCl} / \mathrm{MgO}$. The conversion also decreased from $27.6 \%$ to $24.7 \%$. The most marked change was observed on the $\mathrm{C}_{2} \mathrm{H}_{4} / \mathrm{C}_{2} \mathrm{H}_{6}$ ratio, which decreased from 1.38 to 0.29 . This was observed when $\mathrm{Li}_{2} \mathrm{CO}_{3}$ was used as a precursor. The $\mathrm{C}_{2+}$ selectivity increased to $42.6 \%$ with methane conversion of $29.7 \%$, resulting in $\mathrm{C}_{2+}$ yield of $12.7 \%$. The $\mathrm{C}_{2} \mathrm{H}_{4} / \mathrm{C}_{2} \mathrm{H}_{6}$ ratio also increased to 1.5. All the other measured parameters were kept constant.

For $\mathrm{La}_{2} \mathrm{O}_{3}$, doping it with $2 \mathrm{~mol} \% \mathrm{LiCl}$ caused an increase in $\mathrm{C}_{2+}$ selectivity and yield which were the highest among all the catalysts studied.

Table 1: Catalytic activity of $\mathrm{La}_{2} \mathrm{O}_{3}$ and $\mathrm{MgO}$ based catalysts

\begin{tabular}{cccccccc}
\hline Catalysts & $\begin{array}{c}\% \mathrm{CH}_{4} \\
\text { conversion }\end{array}$ & $\begin{array}{c}\% \mathrm{C}_{2+} \\
\text { hydrocarbons }\end{array}$ & $\begin{array}{c}\% \mathrm{C}_{2+} \\
\text { yield }\end{array}$ & $\begin{array}{c}\% \mathrm{H}_{2} \\
\text { selectivity }\end{array}$ & $\begin{array}{c}\% \mathrm{H}_{2} \\
\text { yield }\end{array}$ & $\mathrm{C}_{2} \mathrm{H}_{4} / \mathrm{C}_{2} \mathrm{H}_{6}$ & $\mathrm{CO} / \mathrm{CO}_{2}$ \\
\hline $\mathrm{MgO}$ & 28.8 & 39.4 & 11.3 & 19.1 & 5.5 & 1.14 & 0.14 \\
$1 \mathrm{~mol} \% \mathrm{LiCl} / \mathrm{MgO}$ & 27.6 & 39.6 & 10.9 & 16.3 & 4.5 & 1.38 & 0.25 \\
$2 \mathrm{~mol} \% \mathrm{LiCl} / \mathrm{MgO}$ & 24.7 & 34.7 & 8.6 & 20.6 & 5.1 & 0.29 & 0.32 \\
$2 \mathrm{~mol} \% \mathrm{Li} / \mathrm{MgO} *$ & 29.7 & 42.6 & 12.7 & 17.0 & 5.1 & 1.5 & 0.25 \\
$\mathrm{La}_{2} \mathrm{O}_{3}$ & 27.7 & 44.8 & 12.4 & 15.8 & 4.4 & 0.95 & 0.11 \\
$1 \mathrm{~mol} \% \mathrm{LiCl} / \mathrm{La}_{2} \mathrm{O}_{3}$ & 28.5 & 44.3 & 12.6 & 14.0 & 4.0 & 0.99 & 0.12 \\
$2 \mathrm{~mol} \% \mathrm{LiCl} / \mathrm{La}_{2} \mathrm{O}_{3}$ & 29.0 & 46.7 & 13.5 & 15.5 & 4.5 & 1.05 & 0.10 \\
$2 \mathrm{~mol} \% \mathrm{Li} / \mathrm{La}_{2} \mathrm{O}_{3} *$ & 27.8 & 42.8 & 11.9 & 12.9 & 3.4 & 0.81 & 0.05 \\
\hline
\end{tabular}

*Prepared by using $\mathrm{Li}_{2} \mathrm{CO}_{3}$ as a precursor for $\mathrm{Li}$ dopant 
The $\mathrm{C}_{2+}$ selectivity and yield of $2 \mathrm{~mol} \% \mathrm{LiCl} / \mathrm{La}_{2} \mathrm{O}_{3}$ were $46.7 \%$ and $13.5 \%$, respectively. The $\mathrm{H}_{2}$ selectivity and yield together with the $\mathrm{C}_{2} \mathrm{H}_{4} / \mathrm{C}_{2} \mathrm{H}_{6}$ and $\mathrm{CO} / \mathrm{CO}_{2}$ ratios did not change significantly. The activity of 2 $\mathrm{mol} \% \mathrm{LiCl} / \mathrm{La}_{2} \mathrm{O}_{3}$ also was better than $2 \mathrm{~mol} \% \mathrm{Li} / \mathrm{La}_{2} \mathrm{O}_{3}$ catalyst prepared by using $\mathrm{Li}_{2} \mathrm{CO}_{3}$ as the $\mathrm{Li}$ dopant precursor, where the $\mathrm{C}_{2+}$ selectivity obtained was $42.8 \%$ with methane conversion of $27.8 \%$. The conversion, yield and selectivity values were reproducible within experimental error of $\pm 5 \%$.

\section{DISCUSSIONS}

It is generally accepted that the oxidative coupling of methane to $C_{2}$ hydrocarbons and subsequently to $C_{3}$ and higher hydrocarbons is initiated by the generation of gas-phase methyl radicals ${ }^{[10]}$. This is accomplished through the abstraction of hydrogen atom from methane, which has been proposed as follows:

$$
\mathrm{CH}_{4}+\mathrm{O}_{\mathrm{s}}^{-}{ }^{\circledR} \mathrm{CH}_{3}+\mathrm{OH}^{-}
$$

where the surface oxygen species, $\mathrm{O}_{\mathrm{s}}^{-}$is the active site. The $\mathrm{OH}^{-}$would be converted to water through subsequent reactions that regenerate the $\mathrm{O}_{\mathrm{s}}^{-}$with the help of gas-phase oxygen. Ethane is formed via the coupling of methyl radicals in the gas phase, whereas ethylene is believed to be originated from the thermal dehydrogenation of ethane or the surface-catalyzed oxidative dehydrogenation of ethane.

Both $\mathrm{CO}$ and $\mathrm{CO}_{2}$ come from the gas-phase or surface catalyzed oxidation of methane, hydrocarbon intermediate species and hydrocarbons final product. The latter two may contribute more significantly than the former for this non-selective reactions ${ }^{[11]}$. The production of hydrogen may be invoked by these possible paths of consecutive reactions ${ }^{[12]}$ :

Water gas-shift reaction (referred to as WGS)

$\mathrm{CO}+\mathrm{H}_{2} \mathrm{O} \circledast \mathrm{CO}_{2}+\mathrm{H}_{2}$

Thermal cracking of ethane

$$
\mathrm{C}_{2} \mathrm{H}_{6}{ }^{\circledR} \mathrm{C}_{2} \mathrm{H}_{4}+\mathrm{H}_{2}
$$

Steam reforming of hydrocarbons

$$
\mathrm{C}_{\mathrm{n}} \mathrm{H}_{2 \mathrm{n}+2}+\mathrm{nH}_{2} \mathrm{O} \circledast \mathrm{nCO}+(2 \mathrm{n}+1) \mathrm{H}_{2}
$$

Partial oxidation of hydrocarbons

$$
\mathrm{C}_{\mathrm{n}} \mathrm{H}_{2 \mathrm{n}+2}+\frac{1}{2} \mathrm{nO}_{2}{ }^{\circledR} \mathrm{nCO}+(\mathrm{n}+1) \mathrm{H}_{2}
$$

Ethane dehydrogenation in the presence of steam is an un-catalyzed commercial process, whereas WGS and steam reforming of hydrocarbons do not proceed without a catalyst. Partial oxidation can occur both thermally and catalytically.

From the figures and table presented, it is noticeable that when the $\mathrm{C}_{2+}$ selectivity increases, the $\mathrm{C}_{2} \mathrm{H}_{4} / \mathrm{C}_{2} \mathrm{H}_{6}$ would also increase but not the $\mathrm{H}_{2}$ selectivity. This indicates that the catalytic oxidative dehydrogenation of ethane and the thermal dehydrogenation of ethane are the sources of ethylene and the water gas-shift reaction (Eq. 8) is the main source of hydrogen production. The catalytic influence on these reactions is clearly shown by the differences in activity of $\mathrm{CaO}$ and $1 \mathrm{~mol} \%$ $\mathrm{LiCl} / \mathrm{CaO}$. The relative importance of the catalytic oxidative dehydrogenation of ethane and the thermal dehydrogenation of ethane is, however, difficult to determine.

The low $\mathrm{CO} / \mathrm{CO}_{2}$ ratio recorded on all the catalysts indicates that the steam reforming of hydrocarbons (Eq. 10) and the partial oxidation of hydrocarbons (Eq. 11) do not proceed to a significant extent. The absence of steam reforming reaction is in line with kinetics observation by Stansch ${ }^{[11]}$ on $\mathrm{La}_{2} \mathrm{O}_{3} / \mathrm{CaO}$ catalyst which stated that the reaction was not observed for reaction temperatures below $800^{\circ} \mathrm{C}$ but become significant above $800^{\circ} \mathrm{C}$. This is because the reaction of $\mathrm{C}_{2+}$ hydrocarbons with water is much slower as compared with oxygen. Investigation by Hargreaves, et. al. ${ }^{[12]}$ showed that partial oxidation of hydrocarbons was found to be the dominant route to $\mathrm{H}_{2}$ only at low oxygen conversion. In the present study, a $100 \%$ of oxygen conversion was achieved on all the catalysts system.

For the catalysts studied, the positive influence of $\mathrm{LiCl}$ on $\mathrm{La}_{2} \mathrm{O}_{3}$ is much more pronounced. The increase in the $\mathrm{C}_{2} \mathrm{H}_{4} / \mathrm{C}_{2} \mathrm{H}_{6}$ ratio may indicate the participation of chlorine in dehydrogenating ethane in the gas phase. As the calcination and reaction temperature used in this study are relatively high, significant loss of chlorine from the catalyst may occur before and definitely after the reaction. This is believed to happen because of the evaporative nature of chlorine. During experimentation, chlorine may react with water vapors resulting in the formation of $\mathrm{HCl}$.

If chlorine induced dehydrogenation of ethane occurred, it is projected that $\mathrm{MgO}$ when doped with 2 mol\% of $\mathrm{LiCl}$ should give a much higher $\mathrm{C}_{2} \mathrm{H}_{4} / \mathrm{C}_{2} \mathrm{H}_{6}$ ratio as compared to $1 \mathrm{~mol} \%$ of $\mathrm{LiCl} / \mathrm{MgO}$. However, this is not the case in our present study. This suggests that other factor, which was influenced by the presence of $\mathrm{Cl}$ plays a part in the catalyst selectivity. The negative effect of chlorine on $\mathrm{MgO}$ is proved further when $\mathrm{Li}_{2} \mathrm{CO}_{3}$ was used as a precursor to prepare 2 $\mathrm{mol} \% \mathrm{Li} / \mathrm{MgO}$, and the $\mathrm{C}_{2+}$ selectivity increased together with the $\mathrm{C}_{2} \mathrm{H}_{4} / \mathrm{C}_{2} \mathrm{H}_{6}$ ratio. The presence of chlorine, however, possibly enhanced the $\mathrm{C}_{2} \mathrm{H}_{4} / \mathrm{C}_{2} \mathrm{H}_{6}$ ratio only at a much lower temperature. A study on $\mathrm{LiCl} / \mathrm{MgO}$ catalyst showed the catalysts to be effective in increasing the ratio of $\mathrm{C}_{2} \mathrm{H}_{4} / \mathrm{C}_{2} \mathrm{H}_{6}$ up to 5 with $\mathrm{C}_{2}$ yield of $20 \%$ at $640^{\circ} \mathrm{C}^{[7]}$.

For $\mathrm{La}_{2} \mathrm{O}_{3}$, higher doping concentration of $\mathrm{LiCl}$ gives a positive effect to the $\mathrm{C}_{2+}$ selectivity but the $\mathrm{C}_{2} \mathrm{H}_{4} / \mathrm{C}_{2} \mathrm{H}_{6}$ ratio remains to be similar. Again, the presence of chlorine is the main factor in the increase of $\mathrm{C}_{2+}$ selectivity as doping the $\mathrm{La}_{2} \mathrm{O}_{3}$ with the same $\mathrm{Li}$ concentration using $\mathrm{Li}_{2} \mathrm{CO}_{3}$ as the precursor do not give a similar result but a decrease in $\mathrm{C}_{2+}$ selectivity as observed. The different behavior of $\mathrm{La}_{2} \mathrm{O}_{3}$ and $\mathrm{MgO}$ based catalysts may be attributed to the influence of chlorine on the active sites of the catalysts. The chlorine seems to affect the catalysts activity more than that of lithium. 


\section{CONCLUSIONS}

Results obtained show that the presence of $\mathrm{LiCl}$ has a marked influence on the activity of all the catalysts studied. The function of the chlorine atom is related more to the active sites on the surface of the catalysts rather than involved in facilitating ethylene formation via gas-phase dehydrogenation reaction of ethane, as previously suggested. It is also discovered that hydrogen is mainly produced through the water gas- shift reaction.

\section{ACKNOWLEDGEMENTS}

This research has been supported by Universiti Sains Malaysia under long-term IRPA grant (Project No. 0202-05-7003). Megat Harun Al Rashid bin Megat Ahmad acknowledges Ministry of Science, Technology and Environment, Malaysia for award of postgraduate scholarship.

\section{REFERENCES}

[1] S. A. Fouda, "Liquid fuels from natural gas", Scientific American, pp. 74-77, March 1998.

[2] M. Max, and W. Dillon, "Natural gas hydrate: a frozen asset?", Chemistry and Industry., pp. 16-18, January 2000.

[3] G. J. Hutchings, J. S. J. Hargreaves, R.W. Joyner and C. J. Kiely, C. J., "Towards understanding of methane coupling" ChemTech, Vol. 24, pp. 25-29, 1994.

[4] A. G. Anshits, E.V. Kondratenko, E. N. Voskresenskaya, L. I. Kurteeva, and N. I., Pavlenko, "The influence of O2 on oxidative coupling of methane over oxide catalysts using N2O as oxidant", Catalysis Today, Vol. 46(2-3), pp. 211-216, 1998.

[5] T. Brousas, P. H. Chiang, D. Eng and M. Stoukides, "Technical and economic evaluation of a methane solid oxide fuel cell", Ionics, Vol. 1, pp. 328-337, 1995.

[6] M. Baerns, O. Buyevskaya and L. Mleczko, "Direct conversion of methane to $\mathrm{C} 2$ hydrocarbons-Is there a prospect for the future?", Proceedings from the European Applied Research Conference on Natural Gas-Eurogas 94-Sintef, Trondheim, pp. 93-113, 1995.

[7] J. H. Lunsford, "The catalytic oxidative coupling of methane", Angewandte Chemie, Vol. 34, pp. 970-980, 1995.

[8] S. Ahmed and J. B. Moffat, "The oxidative coupling of methane on $\mathrm{Mn} / \mathrm{SiO} 2$ and the effect of solid- and gasphase doping", Journal of Catalysis, Vol. 171, pp. 439448, 1999.

[9] J. Zaman, "Oxidative processes in natural gas conversion", Fuel processing Technology, Vol. 58, pp. 61-81, 1999.

[10] N. W. Cant, E. M. Kennedy and P. F. Nelson, "Magnitude and origin of the deuterium kinetic isotope effect during methane coupling and related reactions over $\mathrm{Li} / \mathrm{MgO}$ catalysts", Journal of Physical Chemistry, Vol. 97, pp. 1445-1450, 1993.

[11] Z. Stansch, L. Mleczko and M. Baerns, "Comprehensive kinetics of oxidative coupling of methane over the $\mathrm{La} 2 \mathrm{O} 3 / \mathrm{CaO}$ catalyst", Industrial Engineering and Chemistry Research, Vol. 36, pp. 2568-2579, 1997.
[12] J. S. J. Hargreaves, J. G. Hutchings and R. W., Joyner, "Hydrogen production in methane coupling over magnesium oxide", Natural Gas Conversion, Elsevier, pp. 155-159, 1991.

\section{BIOGRAPHIES}

Muhammad Fadzli bin Mamat received his Diploma in Chemical Engineering from Universiti Teknologi Malaysia in 1993. He worked as a technician at Mobil Malaysia before furthering his study in Chemical Engineering at the School of Chemical Engineering, Universiti Sains Malaysia. He carried out his final year project on the development of catalysts for the oxidative coupling of methane(OCM) under the supervision of Dr. Noor Asmawati and graduated with honors recently.

Dr. Noor Asmawati binti Mohd. Zabidi received her B.S. in chemistry from Nebraska Wesleyan University, Lincoln, USA in 1986. She carried out research in photocatalysis under the supervision of Prof. Timothy F. Thomas at the University of Missouri-Kansas City, USA where she received her Ph.D. in 1995. She has been a lecturer at the School of Chemical Engineering, Universiti Sains Malaysia, Perak Branch Campus since 1996.

Megat Harun Al Rashid bin Megat Ahmad received his B.App.Sc. in analytical chemistry from the School of Chemical Sciences, Universiti Sains Malaysia in 1997. He conducted his MSc. research project on the development of catalyst for the oxidative coupling of methane under the supervision of Dr. Noor Asmawati and Prof. Subhash Bhatia. Previously he has undertaken research on the DPASV and DPP under the supervision of Dr. Sulaiman Ab. Ghani (USM), EIA on Tasik Bera, Pahang, Malaysia (Universiti Malaya-Wetlands International) and the determination of marker for p53 mutation for colon cancer research at the Institute of Medical Research, Malaysia.

Prof. Subhash Bhatia joined School of Chemical Engineering, Universiti Sains Malaysia, Perak Branch Campus, in 1995. He was a Full Professor at the Department of Chemical Engineering, Indian Institute of Technology, Kanpur (India). Prof. Bhatia was a visiting faculty at the University of Queensland, Australia from 1988-89 and 1994-95. His research interests are zeolite catalysis, chemical reaction engineering and environmental catalysis. He has written a book on Zeolite Catalysis that was published by CRC Press, USA and has published more than 60 papers in national and international journals. 